\title{
CONTEMPORARY NEPALI ARTS: AMBIVALENCE AND IN-BETWEEN-NESS
}

\section{DR. YAM PRASAD SHARMA}

\begin{abstract}
Contemporary Nepali arts are connected among each other along with western arts and early Nepali artworks. These artworks share the subject matters, techniques and forms of earlier traditions. Inter-textuality is sometimes created through recycling and appropriation. Similar elements have been used for different purposes. Likewise, similar contents reappear in different forms. Contemporary Nepali arts are the mélange of various cross-currents. Ever-changing alien art influences in the present time have unsettled representational modes of arts. Some art techniques have been borrowed from the western arts, the Hindu and the Buddhist myths and rituals, and native art traditions. The artworks present different elements that have been intertwined. The artworks neither assimilate nor reject the alien art forms but strike balance between them from ambivalent and in-between space. Through the plural art forms, contemporary Nepali arts not only express the feelings of the Nepali artists but also explore the socio-cultural issues of contemporary Nepal. Due the co-presence of diverse images, symbols and forms, the artworks speak of the cultural self and the cultural other. The identities of these art forms are constructed and reconstructed in ambivalent and in-between spaces of local and global influences. Such art forms are plural and open-ended, and their significances or meanings become multiple.
\end{abstract}

Contemporary Nepali arts break the conventional codes. These art forms question and subvert authority.

Cultural identities of contemporary Nepali painting are provisional, dynamic, ever shifting and always on the process of becoming. They are constantly transformed in relation to context and existing power structures of the society. In-between-ness and ambivalence are the dynamisms of contemporary Nepali painting where native and alien art forms come together creating a visual inter-text with multiple meanings and significances.

Globalization has brought cultural encounters in the contact zone. The people of various cultural background have come together. The cross-flow of individuals ultimately has influenced the socio-cultural activities in the native land.

Cultural encounters and differences give way to dialogue and interaction 


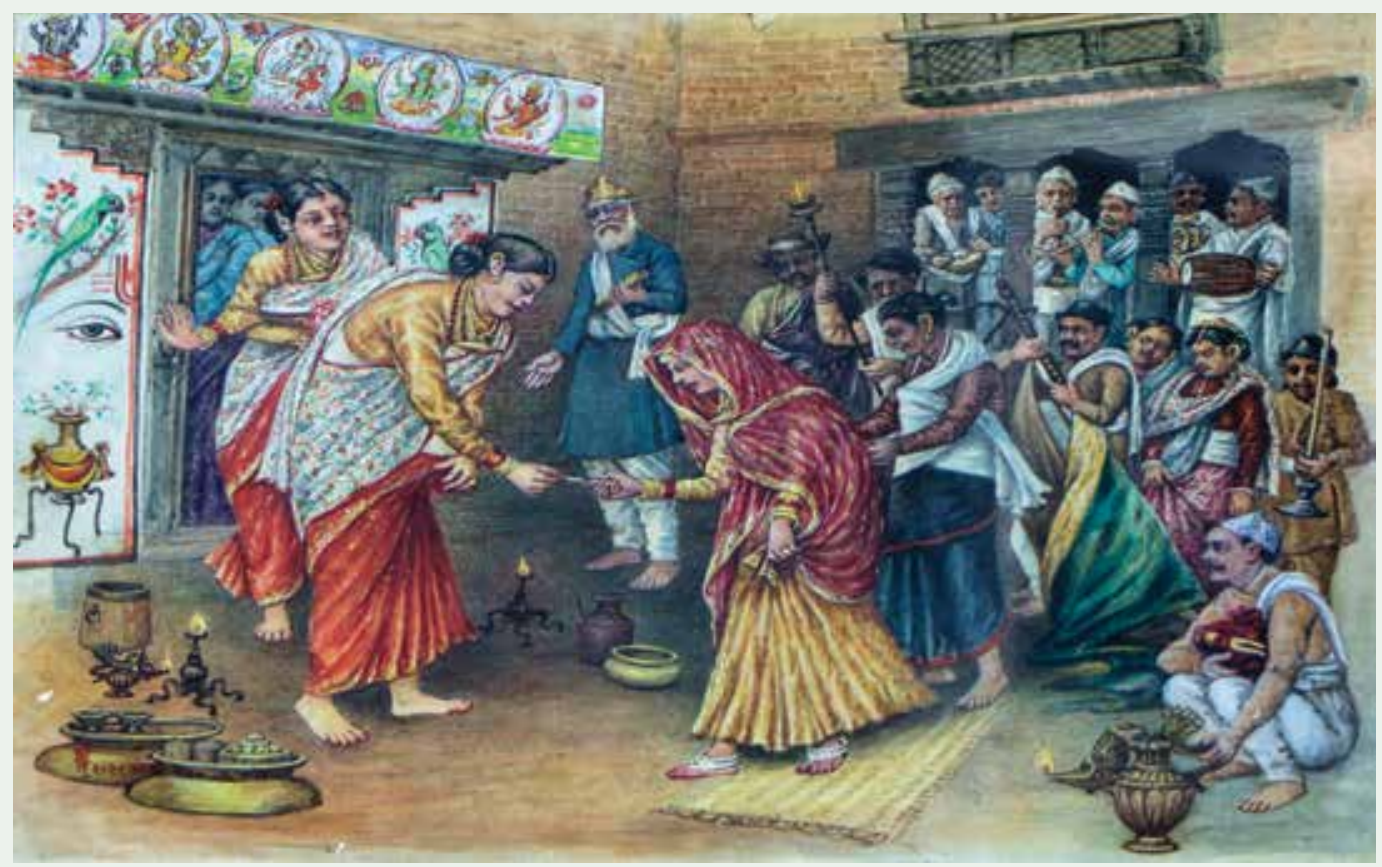

Chandra Man Singh Maskey, 'Bhaumacha' (welcoming of the bride), 1982, Watercolor on paper. Photo courtesy: 'Nepali Art: Issues Miscellany', written by Madan Chitrakar, 2012.

between local and global cultures and arts. Reconstructing identity in contemporary arts is a process of "making local sense of the collision" (Lechner et.al p.320). Remaining at the ambivalent and in-between space, contemporary Nepali artists revise, reread and re-interpret global and local cultures, traditions and artworks.

Nepali artists recycle and reformulate native and alien images through dialogue and interaction. These artworks integrate the images of the Hindu and Buddhist myths with different significances. Such inter-textual art forms are heterogeneous which merge native and alien cultural images creating a mélange. They re-integrate the local and global images. These heterogeneous artworks subvert homogeneity and authority. According to Pieterse (1995), these artworks "unsettle the introverted concept of culture which underlies romantic nationalism, racism, ethnicism, religious revivalism, civilizational chauvinism, and culturalist essentialism" (p.64).

Contemporary Nepali arts are not monolithic but heterogeneous and interconnected. Arts and cultures are not found in fixed but constructed in ambivalent space through appropriation of available different cultures and arts. According to Bhabha (1995), cultures and arts are constructed in "ambivalent space 


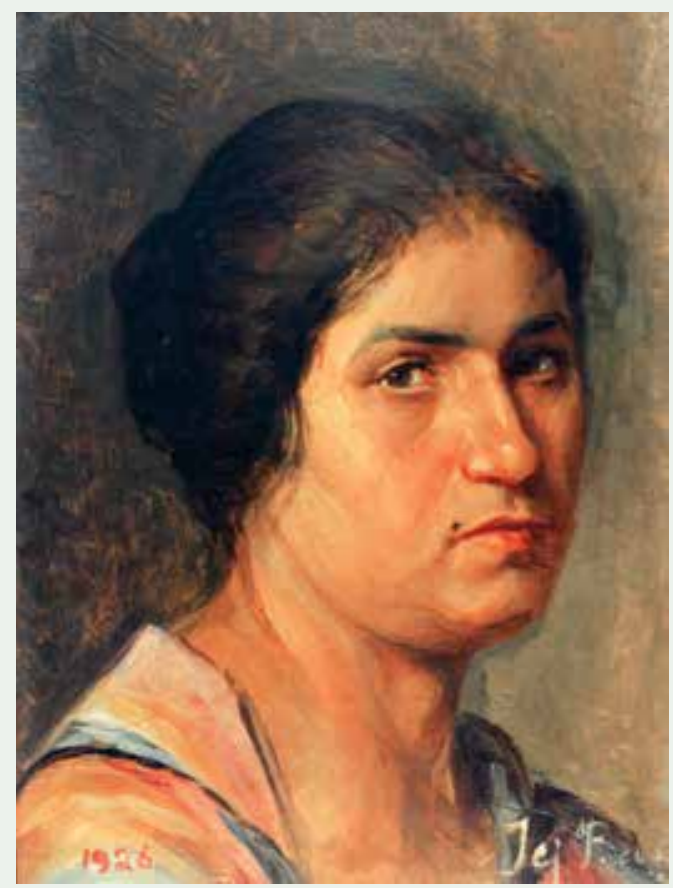

Tej Bahadur Chitrakar, 'A Portrait Study from Life Model', 1926. Oil on canvas.

(Collection: Madan Chitrakar.)

of enunciation, that we begin to understand why hierarchical claims to the inherent originality or 'purity' of cultures are untenable... meaning and symbols of culture have no primordial unity or fixity; that even the same signs can be appropriated, translated, re-historicized, and read anew" (p.208).

No culture is pure. Similarly, contemporary Nepali artworks also share the images of distant cultures. Culture is never just a matter of ownership, of borrowing and lending with absolute debtors and creditors, but rather of appropriations, common experiences and interdependencies of all kinds among different cultures. (pp.261-62)
Heterogeneous art forms are inter-textual because they are interconnected with other works. Earlier art forms are revised and reintegrated. Such features are found even in contemporary Nepali paintings and sculptures. They go beyond own discipline to other disciplines.

Some contemporary Nepali arts share the features of postmodernism. Postmodern artworks do not follow the codes of a particular genre of art. They share the techniques of other art genres. The artwork "blurs genres, transgresses them, or unfixes boundaries that conceal domination or authority" (Cohen 2000 p.293). Such artworks are "multi-generic" having inter-art relationship (Rowe 1992 p.186). They are not governed by the pre-established rules. Such creative process attempts to formulate its own rules in the artwork.

The identity of contemporary Nepali artists is not fixed but ever changing. Cultural identity in art is not found in fixed form but constructed and reconstructed from heterogeneous cultural images through appropriation. The reconstructed cultural identity is not certain and universal but plural and provisional.

Western realistic style influenced the art of portrait painting during the Rana rule from the mid-nineteenth century. Rana Prime ministers, Jung Bahadur and Chandra Sumshere visited Europe, got their portrait 


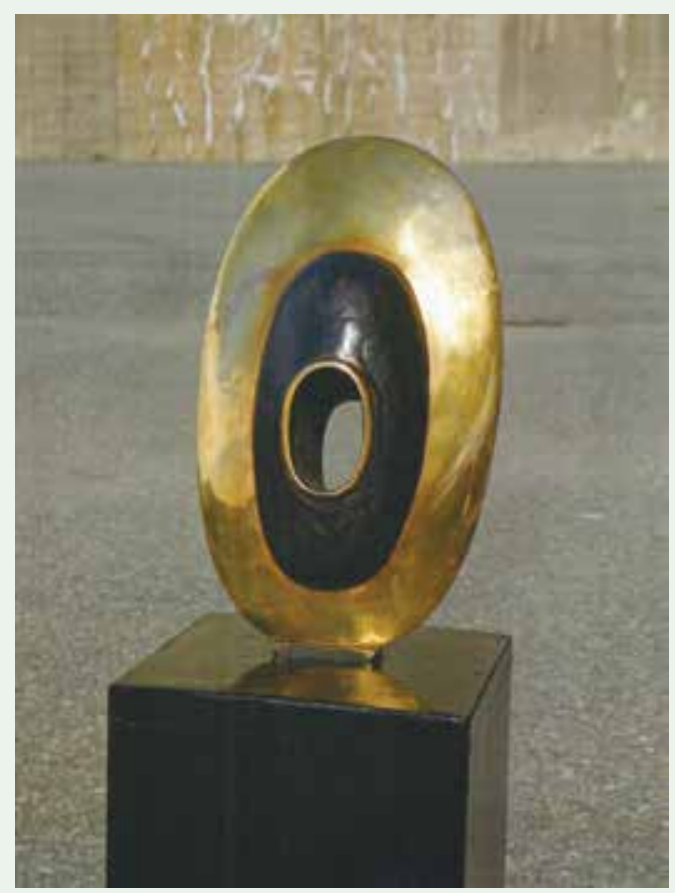

Pramila Giri, 'Bhairav III', 1994. Brass, $23 \mathrm{~cm} \times 42 \mathrm{~cm} \times 17 \mathrm{~cm}$.

made in western style and brought some western paintings home (Singh 1976 pp.35-36). They took Nepali artist in their journey to Europe. The artists like Bhajuman Chitrakar and Dirghaman Chitrakar were exposed to western art forms. These rulers made these artists execute the portraits of themselves and their family members in realistic style. Chandra Sumshere sent Tej Bahadur Chitrakar and Chandraman Maskey for art training in Calcutta. The art school educated the artists in western styles of art. These artists used canvas and western media like oil color, watercolor and pastels for their paintings. The Rana rulers invited even western artists to Nepal to paint their portraits. (Singh
1976 p.40). Pratapaditya Pal (1985) comments on the paintings of the Rana rule, "After the mid-nineteenth century Nepali portraits were rendered entirely in the European tradition" (p.132). Breaking away from religious paintings, realistic style of painting and western media entered in the field of Nepali painting during the Rana rule. Landscapes, still-life paintings, and scenes of hunting of wild animals were painted exploiting western media and realistic style. These paintings break away from mythological motifs of religious arts.

More western influences came to Nepal after the end of Rana autocracy in 1950. Many contemporary Nepali artists went to western and Indian cities for art training. Lain Singh Bangdel, Laxman Shrestha and Urmila Upadhyay took art education from Paris. Pramila Giri and Dipak Simkhada went to America for art education. They learned western techniques of art. Later, they brought home western techniques of painting.

Some contemporary artists went to Indian cities for art education. Uttam Nepali, Ramananda Joshi, Shashi Shah, Batsa Gopal Vaidya, Krishna Manandhar, Govinda Dangol, Madan Chitrakar, Pramila Giri, Kiran Manandhar, Vijay Thapa, Shankar Raj Singh Suwal and Dipak Simkhada are some of them. India remained British colony until 1947, so, western art education was already in practice in India. These artists also brought western influences in the domain of 


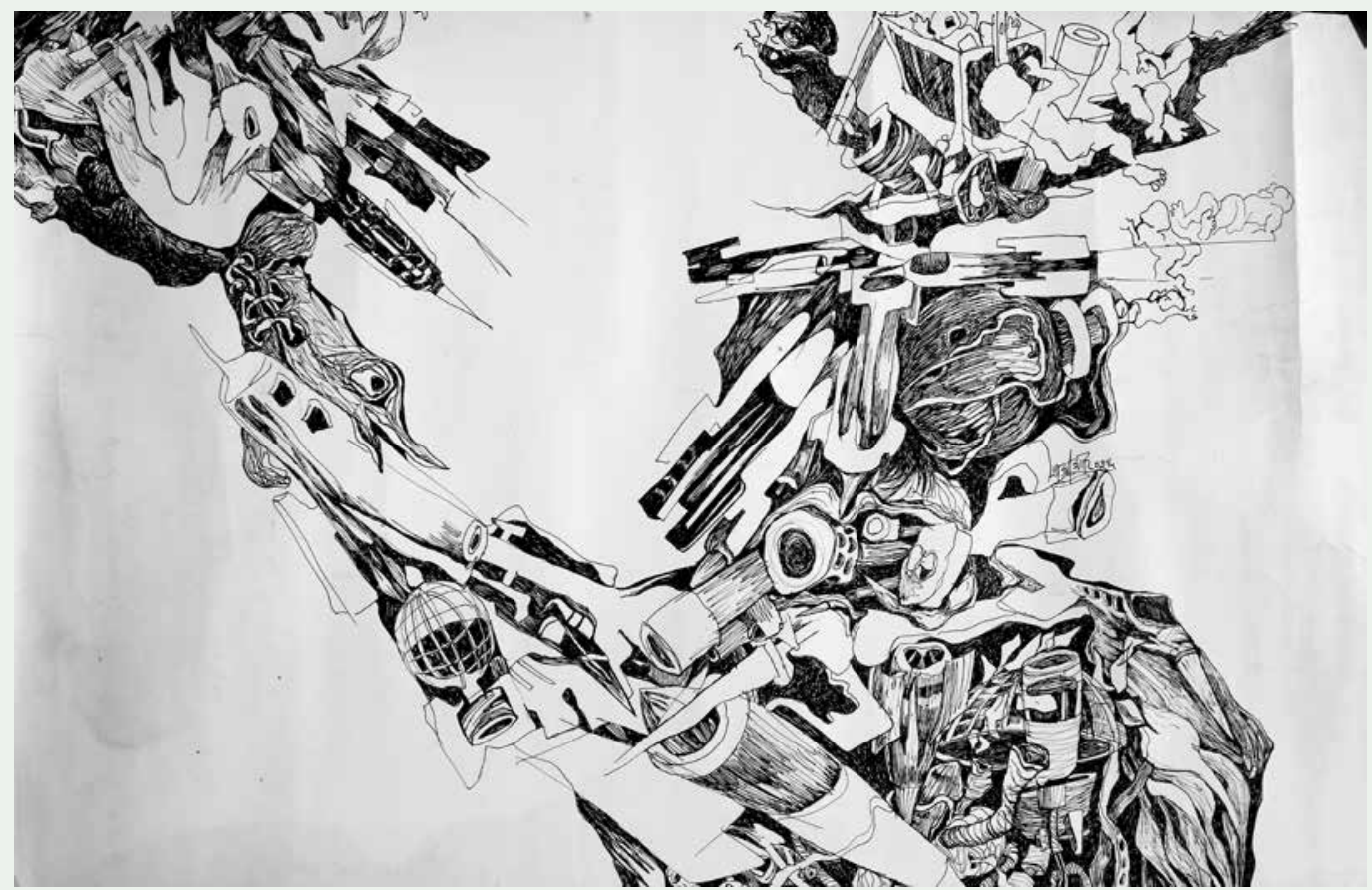

Shashi Shah, 'Chaos of War', 1979. Pen and ink on paper.

Nepali art. Western influence came to Nepal directly and also through India.

Nepali artists came in contact with western art forms and techniques through traveling possibilities and media. These western art techniques helped Nepali artists to break away from referential representations providing the opportunity to express their imagination, inner emotions and personal feelings in the process of creation. Simultaneously, traditional cultural encounters kept on taking place in the contact zone. The referential native art forms and subjective western art forms interacted, cooperated and reintegrated in a single work of art.
In the initial stage, the cultural encounters created complexity in native place. Nepali artists have been attracted toward these plural western art forms because they can provide the opportunities to express their inner emotions. On the other hand, they are interested on using native contents. At this situation, remaining in the ambivalent space, contemporary Nepali arts appropriate western forms and native contents through dialogue and interaction. Cultural interplay and crossovers take place in in-between space. In the process of appropriation, various strategies are used like exploitation of western techniques and the usage of Hindu and Buddhist mythologies and religious imagery. The traditional 


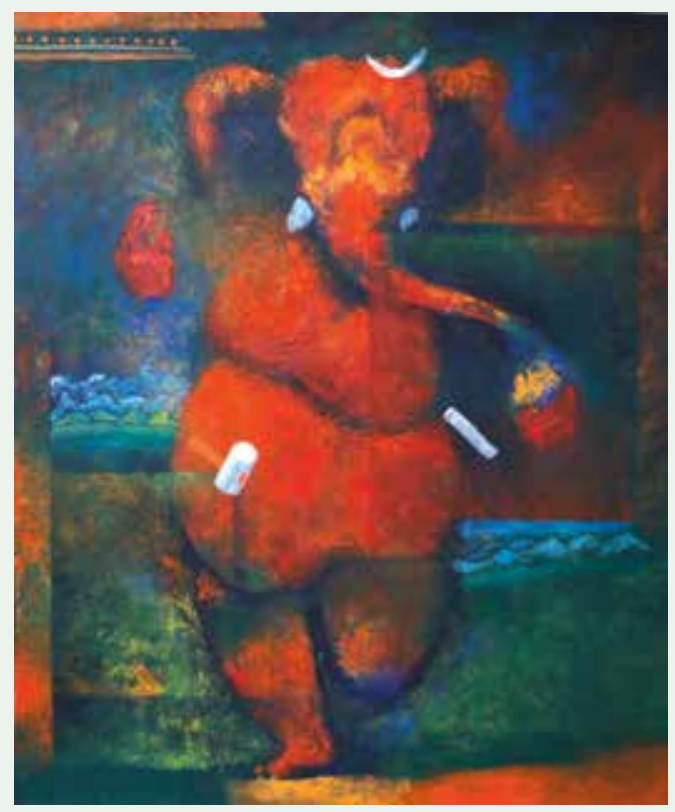

Batsa Gopal Vaidya, 'Ganesh', 2018. Acrylic on canvas.

native forms and western techniques are de-contextualized and re-contextualized. In the process of appropriation, borrowed techniques are used for different purpose in different context. Contents and forms of traditional arts are reinterpreted, re-historicized and reorganized to explore the contemporary sociocultural issues. Established cultural icons are questioned, subverted and menaced. The artworks challenge the authority and homogeneity.

In this sense, contemporary Nepali arts present intercultural appropriation. The works also depict the juxtaposition of visual images and verbal texts in the same canvas. The artists create three dimensional images on the canvas.
Three dimensionality is the feature of sculpture. Photographs on the canvas blur the boundary between high art and low art. Remaining in the dynamism of ambivalent and inbetween space, the artists appropriate heterogeneous images and art forms giving voice to the cultural self and the cultural other. Such reconciliation of diverse cultural elements has broadened the creative possibilities in the domain of contemporary art.

The artworks present inter-textuality between western forms and contents of early Nepali arts. They also explore the theme of meditation and concentration. The Buddhist stupa, meditating sage in padmasana (lotus posture) with vitarkamudra (the gesture of debate), temples, shivalinga, vajra and mandala are recurrent images of native contents treated with western forms. Contrary images are put in unexpected and unusual way. The artworks are inter-textual because they are connected to traditional Nepali arts and architecture, and at the same time, interconnected to the western art form. This is the ambivalent attitude of the artist.

The artworks also integrate native socio-cultural images like typical Nepali cottages and human figures in Nepali dresses. To present these elements, the western technique has been used from the in-between space. The borrowed images have been recontextualized. Contemporary Nepali arts represent both the cultural self 


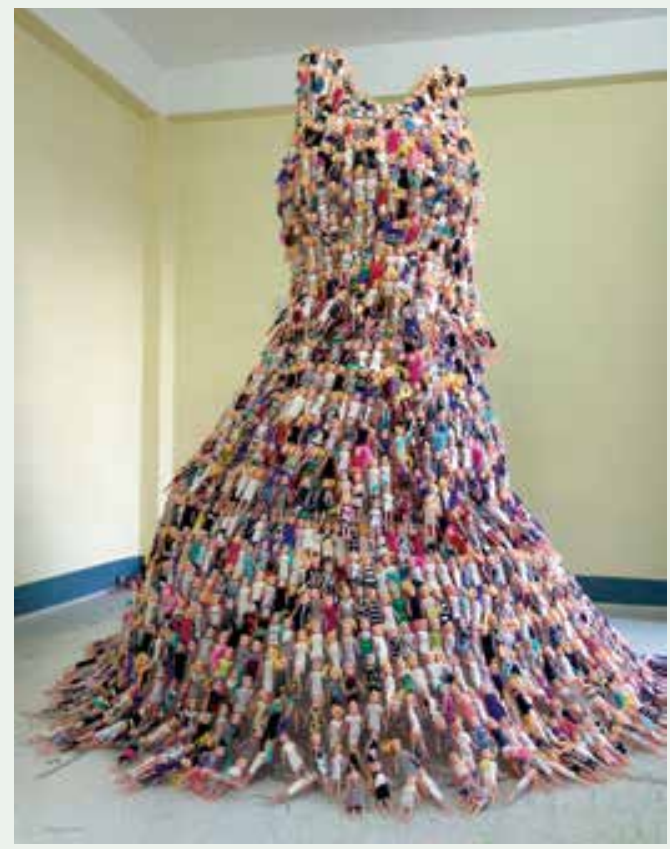

Saur Ganga Darshandhari, 'Flow of Truth', 2013. Installation Art, exhibited in the National Art Exhibition, Nepal Academy of Fine Arts, Kathmandu, 2013.

and the cultural other by integrating different forms of art.

Contemporary Nepali paintings read anew, reinterpret and reintegrate early Nepali paintings. The artists re-historicize and reorganize the forms and contents of these early works to address the issues of contemporary times. They revitalize conventional subject matters, symbols and images exploiting new forms whereas they depict contemporary themes and issues using slightly distorted and altered traditional forms. Traditional symbols and images not only appear with new strength but also the artists recycle them using parody and irony. Sometimes, these contemporary works question, challenge and subvert the authority of early art forms. Contemporary Nepali painting thus does not totally break away from its traditional root but extends and widens its horizon to give expression to the social and geo-political issues of contemporary Nepal.

Globalization has facilitated the creative flow of ideas and events in the domain of Nepali art. The artworks have depicted the concepts like cultural encounter, ambivalence, in-between-ness and appropriation due to the effects of globalization. Native images, symbols, icons and forms are interacting with western techniques and forms in the artworks. The works show cultural self and cultural other. Nepali artists respond and accommodate the foreign forms and techniques in their own creations.

Heterogeneous images and cultures are criss-crossed in the paintings and sculptures. Nepali artists have created plural and subjective artworks by using western techniques. They have recycled and reintegrated the contents of early Nepali arts. The structure of mandala, themes of meditation and religious iconography reappear in unconventional forms. The artists have assimilated their own ancient arts with modern techniques. The structure of mandala, Shivalinga, trident, vajra, lotus and decorative pattern of Mithila folk arts have been presented using expressionist, surrealist and cubist art forms. Dance of Shiva-Shakti has been 
reinterpreted in the contemporary works. Traditional images and subject matters have revived in renewed forms. Continuity and change are the significant features of contemporary Nepali arts.

Some artworks create social and political awareness in contemporary society. The artworks critique the society by depicting the existing contradictions and ironies. These works also function as a satire toward authority and political leadership.

The artworks also cross the boundaries of various disciplines and art genres like music, sculpture, painting, poetry, photography and theatrical performance. The boundaries among various art forms have been blurred to give expression to the creative urge of the artists in relation to the time and space. The individual artwork also looks like a pastiche, for it assembles and integrates the heterogeneous art forms within it. The artist's performance has been accompanied with painting, sculpture, photography and music. Visual arts and verbal arts have been presented together.

Contemporary Nepali arts depict inter-art relationship among various art genres like recitation of scriptures and installation arts as in the Hindu cultural phenomena. Art and religion have been intertwined along with art and life. Creative process has spiritual and pragmatic values. Contemporary Nepali artists have been inspired from such features of rituals. Despite the variation in the mode of presentation, there is the continuity of early traditions. Various art forms are brought together from in-between space.

Some artworks attempt to resolve the dualities between Buddhism and Hinduism, sacred concepts and profane elements, and cosmic being and individual self. There is the play between worldliness and religiosity. Some artworks are objective and referential, for they represent objects and events of myths and external world. But most of the contemporary artworks are subjective, plural and open-ended because of the use of western art forms. These works are ambivalent toward different beliefs and myths.

\section{Conclusion}

Reconciliation of western techniques of art and native subject matters and forms are significant features of contemporary Nepali arts. These works interact with early Nepali arts and contemporary western arts from ambivalent space. External influences have come in the formation of contemporary Nepali arts. Globalization resulted in interconnection of various cultures and arts along with fashion and food. Globalization has brought cultural encounters between western forms and native art contents. It facilitated the cross-flow of artists and art products of different socio-cultural 
space. Due to this, Nepali artists came in contact to the western art forms and techniques. This played important role in the creation of inter-textual artworks. Using western techniques as tools, Nepali artists have reinterpreted the early art forms and revitalized them in contemporary arts.

\section{Contemporary Nepali artworks} have the potentiality of multiple interpretations. Ambivalence and in-between-ness are the dynamisms of the Nepali artworks. Despite such features and characteristics of contemporary Nepali artworks, some questions always come in my mind: Are there any distinct identities of contemporary Nepali arts? Should we follow western modernity to make us modern? Is there the possibility of Nepali modernity in art that are created in different socio-political context? What is exclusive in Nepali art? Are we approaching toward our goal or moving in vicious circle? These curiosities may lead us toward deeper research, interpretation and art criticism.

\section{Works Cited}

Appiach, K. A. (2001). African Identities. Postcolonial Discourses: An Anthology. Ed. Gregory Castle. Oxford: Blackwell.

Axford, B. (1996). The Global System. Cambridge: Polity Press.

Barthes, R. (1992). The death of the author. Critical Theory since Plato. Ed. Hazard Adams. New York: Harcourt Brace Jovanovich College.

Bhabha, H. K. (1995). Cultural Diversity and Cultural Differences: The Post-Colonial Study
Reader. Eds. Bill Ashcroft, Gareth Griffiths and Helen Tiffin. London: Routledge.

Bloom, H. (1988). Poetic origins and final phases. Modern Criticism and Theory. Ed. David Lodge. London: Longman.

Cohen, R. (2000). Do Postmodern Genres Exist? Postmodern Literary Theory: An Anthology. Ed. Oxford: Blackwell.

Delanty, G. (2000). Modernity and Postmodernity: Knowledge, Power and the Self. London: SAGE.

Deleuze, G. et.al (1987). A Thousand Plateaus: Capitalism and Schizophrenia. Trans. B. Massumi. Minneapolis: University of Minnesota Press.

Eco, U. (1988). Casablanca: cult movies and intertexual collage." Modern Criticism and Theory. Ed. David Lodge. London: Longman.

Griffiths, G. (1995). The myth of authenticity. The Post-Colonial Study Reader. Eds. Bill Ashcroft, Gareth Griffiths and Helen Tiffin. London: Routledge.

Hall, S. (1997). Cultural identity and diaspora. Contemporary Postcolonial Theory: A Reader. Ed. Padmini Mongia. Delhi: Oxford UP.

Harvey, D. (2000). Time-space compression and the rise of modernism as a cultural force. The Globalization Reader. Ed. Frank J. Lechner and John Boli. Massachusetts: Blackwell.

Jairazbhoy, R. A. (1965). Oriental Influences in Western Art. Bomboy: Asia Publishing House.

Jameson, F. (1988). The politics of theory: ideological positions in postmodernism debate. Modern Criticism and Theory. Ed. David Lodge. London: Longman.

Kristeva, J. (1992). From one identity to another. Critical Theory since Plato. Ed. Hazard Adams. New York: Harcourt Brace Jovanovich College.

Lassaigne, J. (1959). Matisse: Biographical and Critical Study. Paris: Skira. 
Lechner, F. J. et.al (2000). The Globalization Reader. Massachusetts: Blackwell.

Lyotard, J. (1986). Answering the question: what is postmodernism? The Postmodern Condition.

Trans. R. Durand. Manchester: Manchester UP.

McGrew, A. (1992). A Global Society? Modernity and its Future. Eds. Tony McGrew, Stuart Hall and David Held. New Jersey: Wiley-VCH \& Sons.

Pal, P. (1985). Arts of Nepal: A Catalogue of the Los Angeles County Museum of Art Collection.

Berkeley: Los Angeles County Museum of Art, Wilshire Boulevard and California UP.

Pieterse, N. (1995). Globalization as hybridization. Global Modernities. Eds. Mike Flatherstane, Scott Lash and Roland Robertson. London: Sage.

Reynolds, G. (1946). Twentieth Century Drawings. London: Pleiades Books.

Rowe, J. C. (1992). Postmodernist studies. Redrawing the Boundaries. Eds. Stephen Greenblatt and Giles Gunn. New York: The Modern Language Association of America.

Said, E. (1994). Culture and Imperialism. London: Vintage.

Singh, N. B. (1976). Samasamaik Nepali Chitrakalako Itihas. Kathmandu: Royal Nepal Academy.

Wain, L. (1999). Introduction: Postmodernism? Not Representing Postmodernism. Literary Theories: A Reader and Guide. Ed. Julian Wolfreys. New York: NYUP.

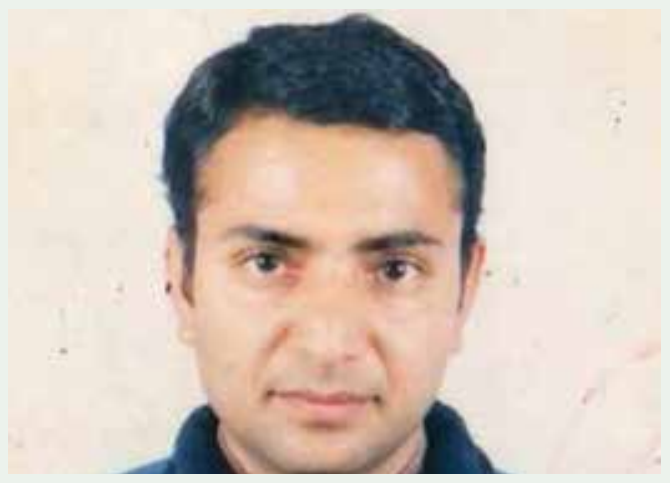

\section{Dr. Yam Prasad Sharma}

Dr. Yam Prasad Sharma is the lecturer of English at Tribhuvan University, Lalitkala Campus. He also teaches Art History and Aesthetics. He conducted research on contemporary Nepali paintings.

He is the author of the book Nepali Paintings: A Critical Analysis, and Co-author of Alternative Art: Shifting Trends in Aesthetics. More than two dozen articles of his have been published in various journals, magazines, newspapers and art exhibition catalogues. 